\title{
Upper Llandovery (Telychian) graptolites of the Oktavites spiralis Biozone from the Long Dai Formation, at Lam Thuy Village, Quang Binh Province, central Vietnam
}

\begin{tabular}{|r|l|}
\hline Journal: & Canadian Journal of Earth Sciences \\
\hline Manuscript ID & cjes-2015-0153.R1 \\
\hline Manuscript Type: & Article \\
\hline Date Submitted by the Author: & $13-$ Jan-2016 \\
\hline List of Authors: & $\begin{array}{l}\text { Williams, Mark; University of Leicester, Department of Geology } \\
\text { Komatsu, Toshifumi; Kumamoto University, Graduate School of Science } \\
\text { and Technology } \\
\text { Tanaka, Gengo; Kumamoto University, Center for Marine Environment } \\
\text { Studies } \\
\text { Huu Hung, Nguyen; Vietnam National Museum of Nature } \\
\text { Zalasiewicz, Jan; University of Leicester, Department of Geology } \\
\text { Vandenbroucke, Thijs R. A.; Ghent University, Department of Geology and } \\
\text { Soil Sciences (WE13) } \\
\text { Wallis, Simon; Nagoya University, Graduate School of Environmental } \\
\text { Studies } \\
\text { Perrier, Vincent; University of Leicester, Department of Geology }\end{array}$ \\
\hline Keyword: & \begin{tabular}{l} 
Graptolites, Silurian, Llandovery, Telychian, Vietnam \\
\hline
\end{tabular} \\
\hline
\end{tabular}

\section{SCHOLARONE \\ Manuscripts}




\section{Upper Llandovery (Telychian) graptolites of the Oktavites}

spiralis Biozone from the Long Dai Formation, at Lam Thuy

Village, Quang Binh Province, central Vietnam

Mark Williams, Toshifumi Komatsu, Gengo Tanaka, Nguyen Huu Hung, Jan

Zalasiewicz, Thijs R. A. Vandenbroucke, Simon Wallis and Vincent Perrier

M. Williams ${ }^{1}$, J. Zalasiewicz and V. Perrier. Department of Geology, University of Leicester, Leicester LE1 7RH, UK

T. Komatsu. Graduate School of Science and Technology, Kumamoto University, 2-39-1, Kurokami, Kumamoto 860-8555, Japan

G. Tanaka. Center for Marine Environment Studies, Kumamoto University, Kamiamakusa City, Kumamoto 861-6102, Japan

Nguyen H.H. Vietnam National Museum of Nature, Vietnam Academy of Science and Technology, 18 Hoang Quoc Viet Road, Cau Giay, Hanoi, Vietnam

T.R.A. Vandenbroucke. Department of Geology (WE13), Ghent University, 9000 Ghent, Belgium

S. Wallis. Graduate School of Environmental Studies, Nagoya University, Chikusa-ku, Nagoya 464-

8601, Japan

${ }^{1}$ Corresponding author (email: mri@le.ac.uk)

Abstract: A numerically small graptolite assemblage from the Long Dai Formation at Lam Thuy village, southwestern Le Thuy district, Quang Binh Province, central Vietnam, includes Oktavites spiralis (Geinitz). The relative abundance of this species in the assemblage, coupled to its occurrence with Oktavites bodentoerlensis Loydell, identifies the upper Silurian (Llandovery Series, Telychian Stage) spiralis graptolite Biozone. Identification of the new locality at Lam Thuy enhances the dataset of Silurian graptolite-bearing localities in central Vietnam and advertises the wide utility of graptolite assemblages for biostratigraphical correlation of lower Palaeozoic strata in northern and central Vietnam.

Keywords: Graptolites, Silurian, Llandovery, Telychian, Vietnam 


\section{Introduction}

Silurian rocks are widely distributed in northern and central Vietnam and were recognised during the 1950s by the geologists of the French Geological Survey of Indochina (Saurin 1956). Silurian sedimentary deposits include those of shallow marine and deep marine successions, the former bearing brachiopod assemblages, whilst the latter yield graptolites: a summary of the Silurian sedimentary deposits of Vietnam was presented by Tong-Dzuy Thanh et al. (2013).

During the early Palaeozoic northeast Vietnam formed a component of the South China Plate with central Vietnam part of the Annamia (aka Indochina, Indosinia) palaeocontinent, the latter being in close geographical proximity to South China during the Silurian (e.g. Tong-Dzuy Thanh et al. 2001; Wang and Zhang 2009; Cocks and Torsvik 2013). The graptolite assemblages of Vietnam are therefore important for regional correlation (Nguyen Van Phuc 2002), but also potentially for constraining the biostratigraphic ages of shelly fauna (e.g. Tong-Dzuy Thanh et al. 2001) used to recognise palaeobiogeographical relationships with other East Asian terranes during the early Palaeozoic.

Graptolites have previously been extensively recorded from the Upper Ordovician and Silurian Song Ca, Long Dai, Phu Ngu, Tan Mai, and Co To formations of Vietnam. Graptolites have also been reported from the Ket Hay (Silurian) and Tay Trang formations (Silurian and Devonian) (see Nguyen Van Phuc 1998 for the Tay Trang graptolite assemblage; and the summary in Tong-Dzuy Thanh et al. 2013 for the other graptolite occurrences). Whilst the stratigraphical utility of graptolites is widely recognised in Vietnam (Nguyen Van Phuc 2002; Tong-Dzuy Thanh et al. 2013), much work needs to be undertaken to provide detailed illustrations of graptolite assemblages to enhance regional biostratigraphical correlation.

Here we document and figure a small assemblage of graptolites serendipitously recovered from Silurian strata at Lam Thuy village ( $N 17^{\circ} 05^{\prime} 06^{\prime \prime}, \mathrm{E}$ $\left.106^{\circ} 36^{\prime} 22^{\prime \prime}\right)$, southwestern Le Thuy district, Quang Binh Province (Figs 1, 2). The graptolites can be firmly assigned to the spiralis graptolite Biozone of the Silurian Llandovery Series and they occur together with small brachiopods in a thick grey mudstone intercalated with calcareous fine sandstone layers interpreted to represent the Long Dai Formation. 


\section{Geological setting of the graptolites}

The Long Dai Formation is composed of up to circa $1900 \mathrm{~m}$ of terrigenous sedimentary rocks thought to represent deposition in a deep marine setting: the formation unconformably overlies the A Vuong Formation which is assigned to the Cambrian and Ordovician, and is unconformably overlain by the Dai Giang Formation that is of Silurian age. In its lower part, the Long Dai Formation yields trilobites interpreted to be of Late Ordovician age, whilst in its upper part mudstones yield graptolites that have been identified as Neodiversograptus nilssoni (Barrande) and Bohemograptus bohemicus (Barrande) indicative of the late Silurian, Ludlow Epoch (Tong-Dzuy Thanh et al. 2013 and references therein). Previous records of early Silurian (Llandovery) graptolites in the Long Dai Formation have noted the presence of 'Demirastrites' (= Lituigraptus) convolutus (Hisinger), Stimulograptus halli (Barrande) and Oktavites spiralis (Geinitz), indicating material collected from several biostratigraphical horizons (Nguyen Xuan Duong 1996; Tong-Dzuy Thanh and Vu Khuc 2006; Tong-Dzuy Thanh et al. 2013). Graptolite assemblages assigned to the spiralis Biozone have previously been documented from central Vietnam, at a locality in the Long Dai river valley of Quang Ninh district, Quang Binh Province, and from a stream section in the northwest part of the Da Mao Mountains - Le Ky railway station area (Nguyen Van Phuc 2002).

\section{Biostratigraphy}

Graptolites from the Long Dai Formation at Lam Thuy village are illustrated in Figures 3 to 5. The assemblage is from a single horizon (Fig. 2), comprising 18 graptolite-bearing rock slabs (including part and counterparts). There are some 25 graptolites identifiable to generic level (Oxford University Museum of Natural History numbers OUMNH CY.1 to CY.25) with additional indeterminate fragments. One rock slab preserves a fragment of shell.

The graptolites include the biozonal index fossil Oktavites spiralis (Geinitz) (Figs 3a-e), the most common graptolite in the assemblage. O. spiralis has a short biostratigraphic range, which in the UK is restricted to the spiralis and lower part of the succeeding lapworthi graptolite biozones (see Zalasiewicz et al. 2009). In 
Bohemia $O$. spiralis is recorded through a similar biostratigraphical range: appearing (albeit rarely) towards the top of the tullbergi graptolite Biozone at a similar level with Monograptus parapriodon Bouček; ranging through the spiralis Biozone where its sudden abundance defines the base of the biozone; and extending into the lower part of the succeeding grandis Biozone (Štorch 1994). O. spiralis is recorded from its eponymous biozone in the Baltic region (e.g. Loydell et al. 2010), where its earliest occurrence is also associated with that of $M$. parapriodon (Loydell et al. 1998). In the Jabalón River section of central Spain O. spiralis appears at the base of its eponymous biozone, overlaps with the range of $M$. parapriodon, and extends through the succeeding lapworthi Biozone (Loydell et al. 2009). As O. spiralis is the most abundant graptolite in the assemblage at Lam Thuy, and since it co-occurs with Oktavites bodentoerlensis Loydell (Fig. 3f) that is characteristic for the lower spiralis Biozone in Austria (Loydell 2003) and New South Wales, Australia (Rickards et al. 2004), we use these graptolites to identify a spiralis graptolite Biozone age at Lam Thuy.

The assemblage at Lam Thuy also includes Pristiograptus and Monograptus species, but these are less identifiable because of poor and fragmentary preservation. They include two specimens referred tentatively to Pristiograptus cf. initialis Kirste (Fig. 4d, f). P. initialis is known to occur at pre-spiralis Biozone horizons elsewhere, for example questionably from the griestoniensis graptolite Biozone and confirmed from the crenulata graptolite Biozone in the UK (Zalasiewicz 1994;

Zalasiewicz et al. 2009). P. initialis is also identified as possibly ancestral to the longranging (Wenlock and Ludlow Series) Pristiograptus dubius (Suess) group (Rickards and Wright 2003) and the species has also been recorded at the same stratigraphical level as questionable $O$. spiralis in the Broken River region of Queensland, Australia (Rickards and Jell 2002).

Other graptolites at Lam Thuy include Monograptus cf. priodon (Bronn) (Fig. 4a), and an indeterminate retiolitid (Fig. 5). M. priodon is a biostratigraphically longranging Telychian and early Wenlock species.

\section{Notes on the illustrated graptolites}


The graptolite-bearing mudrocks are heavily weathered at outcrop and the graptolites are largely preserved in iron oxide (Fig. 5). We note that there is some evidence for slight distortion of the graptolites, though we are not able to determine a tectonic fabric on the surfaces of the mudrock slabs.

Specimens of $O$. spiralis (Fig. 3a-e) show whorl diameter that approximately doubles for each spiral. They have a distal '2 theca repeat distance' ('2TRD' sensu Howe 1983) of between circa 1.7 to $2.1 \mathrm{~mm}$, with dorsoventral widths of between 2.5 to $3 \mathrm{~mm}$; more proximally, dorsoventral widths are about $1.6 \mathrm{~mm}$. The specimens accord well with the dimensions of those $O$. spiralis figured by Loydell et al. (2003, fig. 7m, v; 2010, fig. 2x, dd) from Latvia, and from central Spain (Loydell et al. 2009, fig. 4e, h, i, o, y).

The single specimen of $O$. bodentoerlensis (Fig. 3f) from Lam Thuy accords with the overall morphology of specimens of this species figured from the spiralis Biozone of Austria by (Loydell 2003, text-fig. 1.14-17) and Australia by Rickards et al. (2004, fig. 3i, j), particularly in its dorsal curvature, which is most rapid between theca 2 and theca 4. It is slightly broader than the Austrian specimens, with a dorsoventral width of circa $0.8 \mathrm{~mm}$ at the level of theca 1 , and $0.9 \mathrm{~mm}$ at the level of theca 3, and has more widely spaced thecae, with 2TRD of $2.3 \mathrm{~mm}$ at theca 4.

Two Pristiograptus specimens lacking proximal ends are tentatively assigned to $P$. cf. initialis Kirste (Fig. 4d, f) based on their weakly geniculate thecae and slowly expanding dorsoventral width that approaches a maximum of $0.9 \mathrm{~mm}$, with distal 2TRD of between 1.95 to $2.2 \mathrm{~mm}$. Though less well preserved, their dimensions are comparable to those of $P$. initialis figured by Zalasiewicz from the UK (1994, text-fig. $8 \mathrm{G})$ and by Rickards and Jell (2002, fig. 5E) from Australia.

A single specimen referred to Monograptus cf. priodon (Fig. 4a) lacks its proximal end but has a distal 2TRD of $2 \mathrm{~mm}$ and dorsoventral width of $2.3 \mathrm{~mm}$. Other specimens of Monograptus (e.g. Fig. 4b, c) have narrower dorsoventral widths of less than $2 \mathrm{~mm}$.

\section{Conclusions}

The small collection of graptolites from Lam Thuy village in Quang Binh Province, central Vietnam identifies the Telychian spiralis graptolite Biozone in strata 
of the Long Dai Formation. These add to the dataset of Silurian graptolite-bearing localities in central Vietnam, support the previous identification of spiralis Biozone graptolites from this region (Nguyen Van Phuc 2002), and emphasise the utility of graptolites for providing biostratigraphical ties for the regional correlation of various lithostratigraphic schemes of central and northern Vietnam (Tong-Dzuy Thanh et al. 2013). The record of Oktavites bodentoerlensis from Vietnam, a species previously recorded from Austria (Loydell 2003) and Australia (Rickards et al. 2004), demonstrate that $O$. bodentoerlensis is of widespread use for international correlation of the spiralis graptolite Biozone.

\section{Acknowledgements}

We thank our colleagues at the Vietnam National Museum of Nature (VNMN) and Vietnam Academy of Science and Technology (VAST), Hanoi, for their help with fieldwork and David Siveter (Leicester) for his initial observations on the graptolites. The authors thank the Leverhulme Trust (International Network Grant IN-2014-025 'Assembling the Early Palaeozoic terranes of Japan') and the Japan Society for the Promotion of Science for funding our collaboration. We are grateful to the reviewers for their careful comments on the manuscript. This is a contribution to IGCP 591.

\section{References}

Cocks, L.R.M., and Torsvik, T. 2013. The dynamical evolution of the Palaeozoic geography of eastern Asia. Earth Science Reviews, 117: 40-79.

Howe, M.P.A. 1983. Measurement of thecal spacing in graptolites. Geological Magazine, 120: 635-658.

Loydell, D.K. 2003. Late Telychian graptolites of the Rauchfkofel Bodentörl section (central Carnic Alps, Austria). Jahrbuch der Geologisches Bundesanstalt, 143: 5761.

Loydell, D.K., Kaljo, D., and Männik, P. 1998. Integrated biostratigraphy of the lower Silurian of the Ohesaare core, Saaremaa, Estonia. Geological Magazine, 135: 769783.

Loydell, D.K., Männik, P., and Nestor, V. 2003. Integrated biostratigraphy of the lower Silurian of the Aizpute-41 core, Latvia. Geological Magazine, 140: 205-229. 
Loydell, D.K., Sarmiento, G.N., Štorch, P., and Gutiérrez-Marco, J.C. 2009. Graptolite and conodont biostratigraphy of the upper Telychian-lower Sheinwoodian (Llandovery-Wenlock) strata, Jabalon River section, Corral de Calatrava, central Spain. Geological Magazine, 146: 187-198.

Loydell, D.K., Nestor, V., and Männik, P. 2010. Integrated biostratigraphy of the lower Silurian of the Kolka-54 core, Latvia. Geological Magazine, 147: 253-280.

Nguyen Van Phuc. 2002. Ordovician-Silurian and lower Devonian graptolite bearing beds from Vietnam. Vietnam National University, Journal of Science, Natural Sciences and Technology, 18: 38-50.

Nguyen Van Phuc. 1998. Lower Devonian Graptolites from Muong Xen area (Northwest part of Central Viet Nam). Journal of Geology, Hanoi, Series B, 11-12: 29-40.

Nguyen Xuan Duong. 1996. Geological Maps on Scale 1: 200000 with Explanatory Note. Le Thuy-Quang Tri Sheet. Department of Geology of Viet Nam, Ha Noi.

Rickards, R.B., and Jell, J.S. 2002. New graptolite faunas from the Llandovery, lower Silurian of the Graveyard Creek subprovince, Broken River region, Queensland, Australia. Proceedings of the Geologists' Association, 113: 111-120.

Rickards, R.B., and Wright, A.J. 2003. The Pristiograptus dubius (Suess, 1851) species group and iterative evolution in the mid- and late Silurian. Scottish Journal of Geology, 39: 61-69.

Rickards, R.B., Parkes, R.A., and Wright, A.J. 2004. Llandovery (Early Silurian) graptolites from the Quidong Basin, NSW. Proceedings of the Linnean Society of New South Wales, 126: 143-152.

Saurin, E. 1956. Indochine. In 'Lexique stratigraphique International'. III/6a. Centre National de la recherche Scientifique Paris. 140 pp.

Štorch, P. 1994. Graptolite biostratigraphy of the Lower Silurian (Llandovery and Wenlock) of Bohemia. Geological Journal, 29: 137-165.

Tong-Dzuy Thanh, and Vu Khuc (Eds.) 2006. Stratigraphic Units of Viet Nam. Ha Noi National University Publishing House, 526 pp., Ha Noi.

Tong-Dzuy Thanh, Boucot, A.J., Rong, J.-Y., and Fang, Z.-J. 2001. Late Silurian marine shelly fauna of central and northern Vietnam. Geobios, 34: 315-338.

Tong-Dzuy Thanh, Ta-Hoang Phuong, Janvier, P., Nguyen Huu Hung, Nguyen Thi Thu 
Cuc, and Nguyen Thuy Dong. 2013. Silurian and Devonian in Vietnam Stratigraphy and facies. Journal of Geodynamics, 69: 165-185.

Wang, Y., and Zhang, Y.-D. 2009. Llandovery sporomorphs and graptolites from the Manbo Formation, the Mojiang County, Yunnan, China. Proceedings of the Royal Society, Series B, 277: 267-275.

Zalasiewicz, J.A. 1994. Middle to late Telychian (Silurian: Llandovery) graptolite assemblages of central Wales. Palaeontology, 37: 375-396.

Zalasiewicz, J.A., Taylor, L., Rushton, A.W.A., Loydell, D.K., Rickards, R.B., and Williams, M. 2009. Graptolites in British stratigraphy. Geological Magazine, 146: 785-850.

Fig. 1. Geographical location of the graptolite-bearing locality ( $N 17^{\circ} 05^{\prime} 06^{\prime \prime}, \mathrm{E} 106^{\circ}$ 36' 22") at Lam Thuy village, Quang Binh Province, central Vietnam.

Fig. 2. Graptolite-bearing strata of the Long Dai Formation at Lam Thuy, Quang Binh Province, central Vietnam.

Fig. 3. Camera lucida drawings of Oktavites graptolites from the Long Dai Formation at Lam Thuy, Quang Binh Province, central Vietnam: a-e, Oktavites spiralis (Geinitz), OUMNH CY.7a, CY17, CY10, CY.5 and CY.4a respectively; f, Oktavites bodentoerlensis Loydell, OUMNH CY.2. Scale bars are $2 \mathrm{~mm}$. Specimen numbers (OUMNH) are those of the Oxford University Museum of Natural History, Parks Road, Oxford, OX1 3PW, United Kingdom.

Fig. 4. Camera lucida drawings of graptolites from the Long Dai Formation at Lam Thuy, Quang Binh Province, central Vietnam: a, Monograptus cf. priodon (Bronn), OUMNH CY.6; b, Monograptus sp. indet. A, OUMNH CY.18; c, Monograptus sp. indet. B, CY.19a; d, f, Pristiograptus cf. initialis Kirste, OUMNH CY.21 and CY.20 respectively; e, Pristiograptus sp. indet., OUMNH CY.22; g, Monograptus sp. indet. C, OUMNH CY.25a. Scale bars are $2 \mathrm{~mm}$. Repository as for Figure 3. 
Fig. 5. Retiolitid graptolite OUMNH CY.1, preserved largely as iron oxide, from the Long Dai Formation at Lam Thuy, Quang Binh Province, central Vietnam. This

graptolite is used to illustrate the general preservation of specimens. Scale bar is 1 $\mathrm{mm}$. Repository as for Figure 3. 

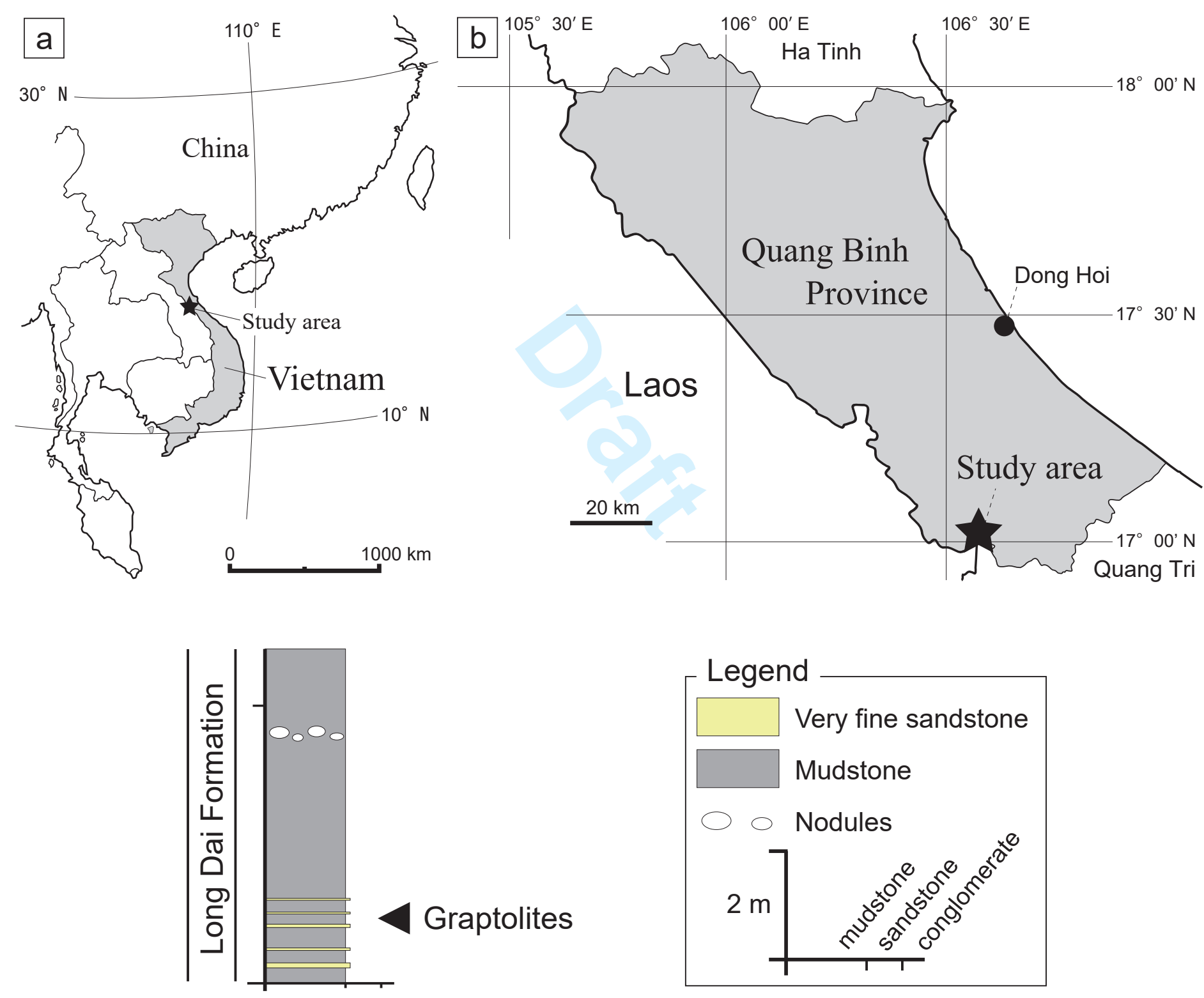

$17^{\circ} 05^{\prime} 06^{\prime \prime} \mathrm{N}$

$106^{\circ} 36^{\prime} 22^{\prime \prime} \mathrm{E}$ 


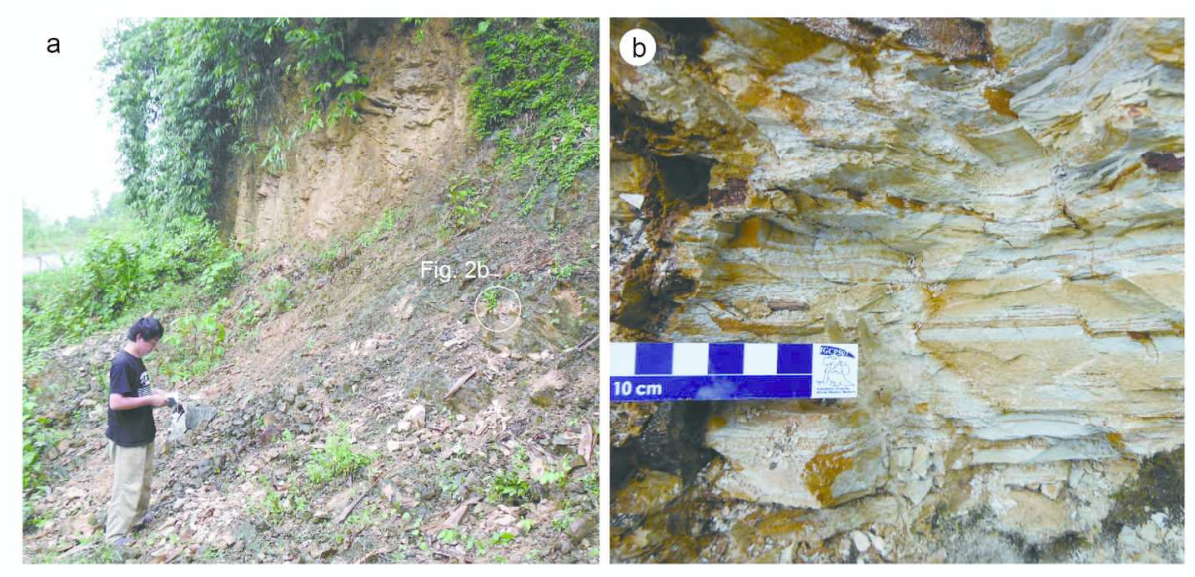

$200 \times 126 \mathrm{~mm}(300 \times 300 \mathrm{DPI})$ 


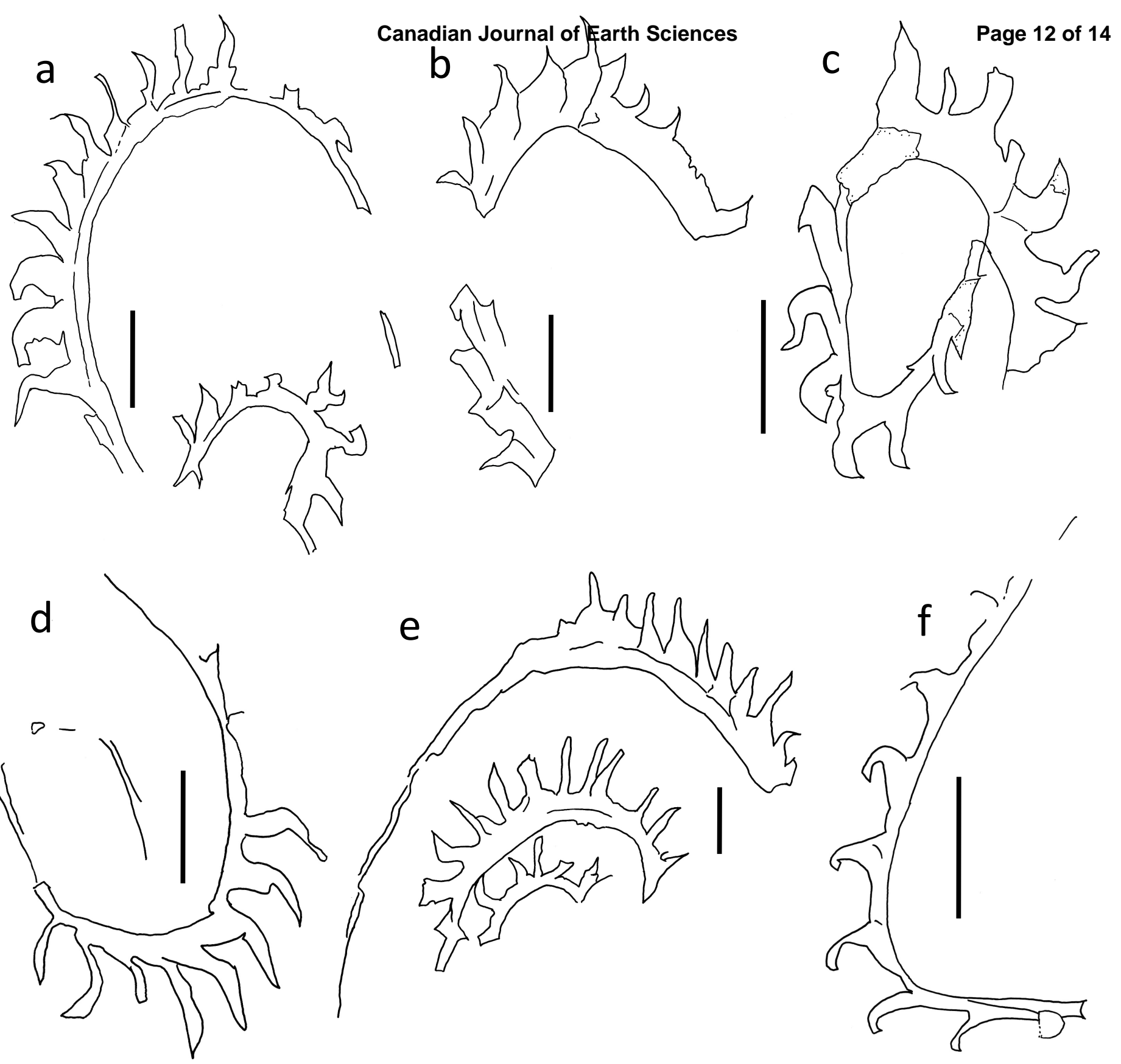


Page 13 of 14

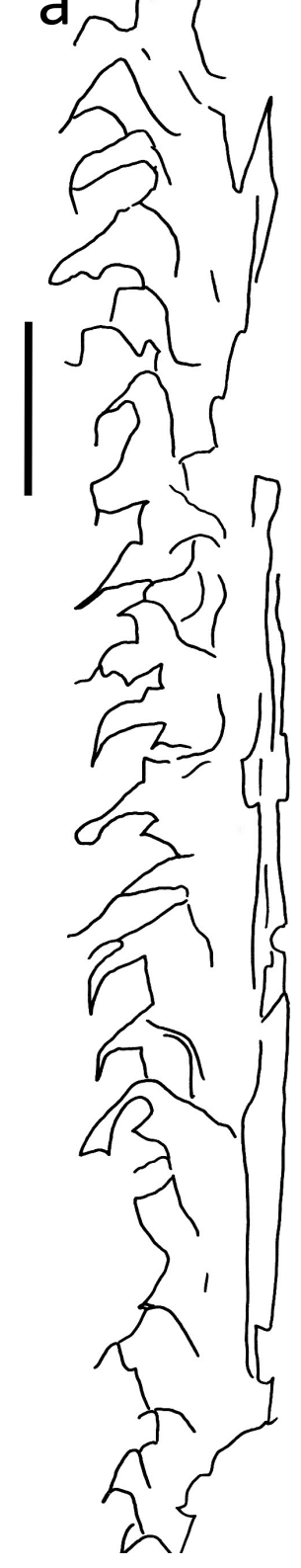

Ganadian Journal of Earth Sciences
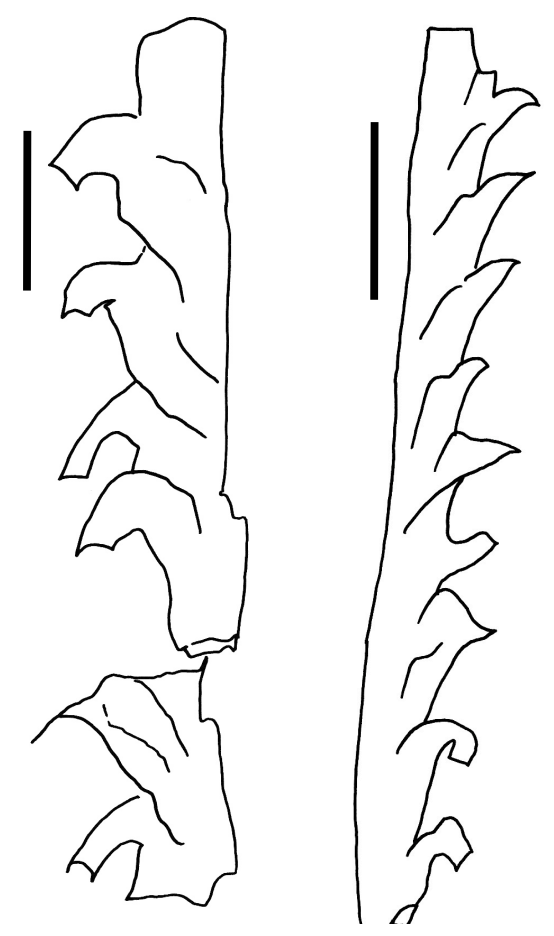

ry

e
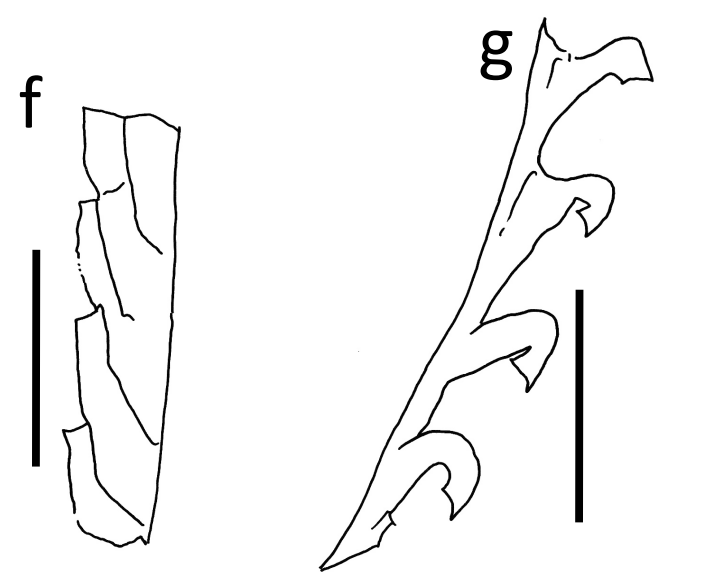

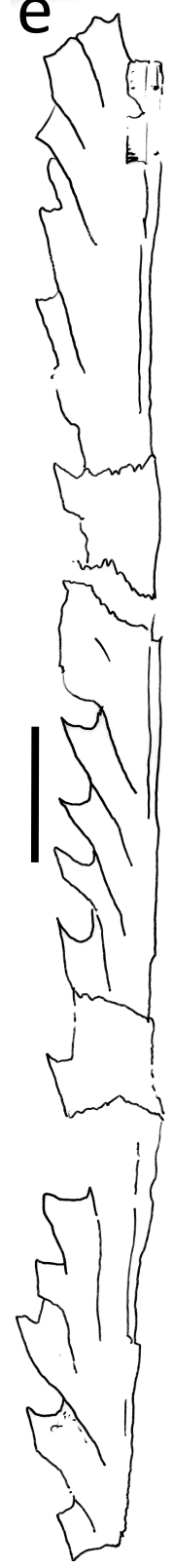




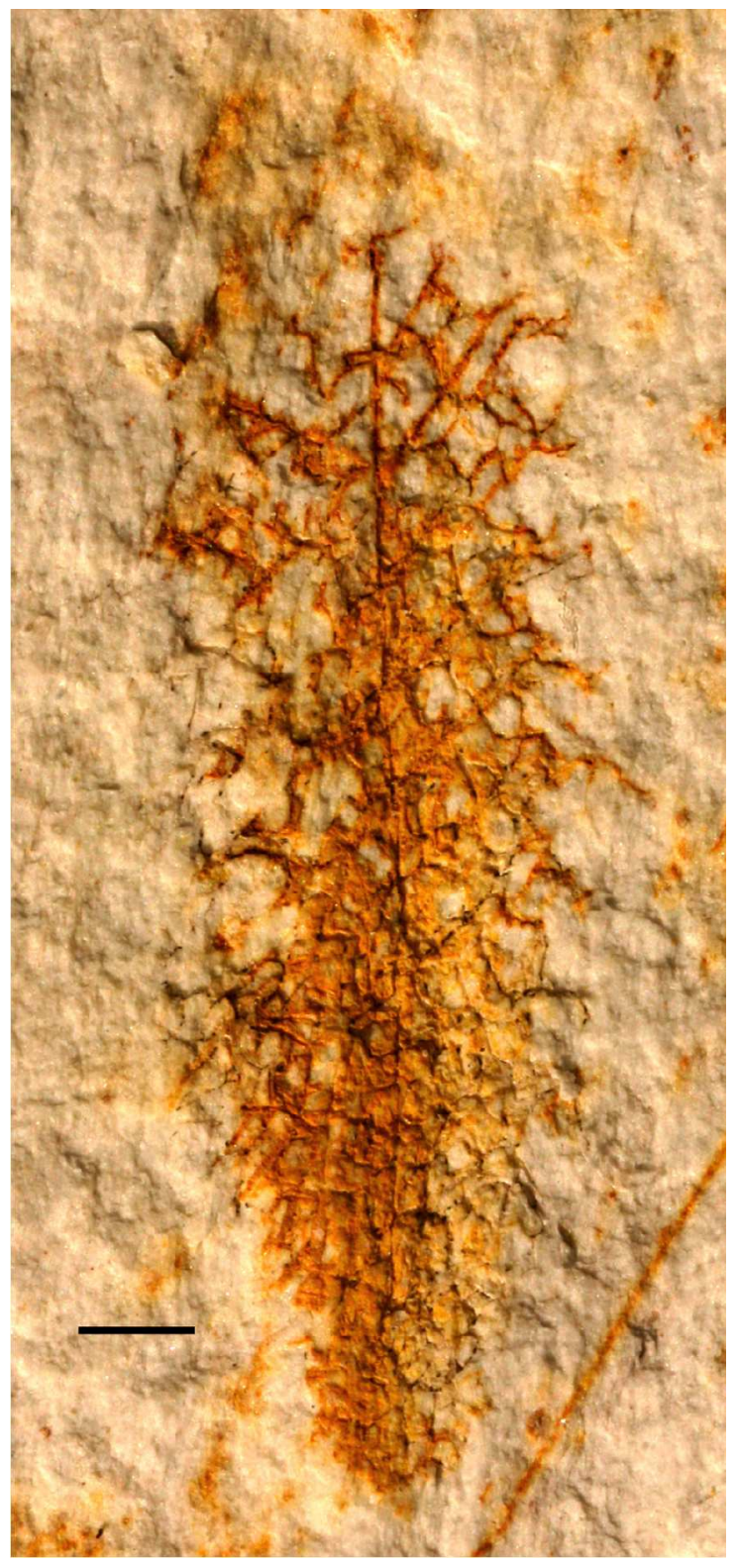

$102 \times 222 \mathrm{~mm}(300 \times 300 \mathrm{DPI})$ 